\title{
Innocent PET avidity in patient with metastatic melanoma
}

\author{
Liam Peng, ${ }^{1}$ Rhiannon McBean ${ }^{2}$
}

${ }^{1}$ The Wesley Hospital, Brisbane, Queensland, Australia ${ }^{2}$ The Wesley Hospital, Wesley Medical Imaging, Brisbane, Queensland, Australia

\section{Correspondence to} Dr Rhiannon McBean, research@ucmi.com.au

Accepted 26 July 2018
Check for updates

(c) BMJ Publishing Group Limited 2018. No commercial re-use. See rights and permissions. Published by BMJ.

To cite: Peng L, McBean R. BMJ Case Rep Published Online First: [please include Day Month Year]. doi:10.1136/bcr-2018226140

\section{DESCRIPTION}

A 53-year-old man presented for a surveillance ${ }^{18}$ F-fluorodeoxyglucose (FDG) positron emission tomography (PET)/CT following recent resection of a melanoma of his right leg and metastasis to his right inguinal region. The scan was acquired approximately $60 \mathrm{~min}$ after intravenous injection of FDG. The FDG-PET/CT scan demonstrated no FDG uptake in the right inguinal region. However, intense FDG uptake was observed in skeletal muscles, specifically in the left foot (figure 1A) and around the shoulder, bicep and pectoral regions bilaterally (figure $1 \mathrm{~B}, \mathrm{C}$ ).

FDG-PET/CT is an integral part of modern-day practice in oncology imaging and has been shown to have high sensitivity and specificity for the detection of melanoma metastasis. ${ }^{1}$ Concerned by the intense avidity seen in this case, the attending radiologist queried the patient who denied any recent physical activity. Further discussion led to the elucidation that the patient was using crutches postresection, explaining the high metabolic activity in the relevant regions. Follow-up surveillance FDG-PET/CT 3 months later showed no unexpected avidity indicating the patient was cured of his melanoma and was no longer on crutches. Twelve months later, the patient continues to be in remission.

FDG uptake is not tumour specific. Different pathological and physiological conditions such as inflammation, infection, surgery, strenuous exercise and artefact can all cause false-positive results. Previous cases of false-positive FDG-PET/CT in patients with melanoma have been described by Vensby et al. ${ }^{2}$ to be observed in around $10 \%$ of cases, most of which are due to the increased FDG uptake by inflammatory cells. Misinterpretations in PET/ CT analysis may result in psychological distress and
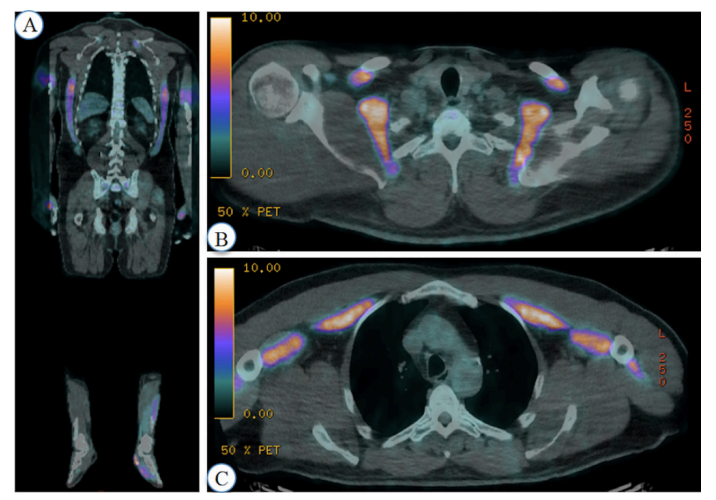

Figure $1{ }^{18} \mathrm{~F}$-fluorodeoxyglucose positron emission tomography showed intense uptake within the left foot (A) and around the shoulder (B), bicep and pectoral regions bilaterally $(C)$.

\section{Learning points}

- Proper patient preparation is essential in order to differentiate physiologic skeletal muscle FDG uptake from pathological involvement.

- Patients should avoid strenuous exercise for preferably 24 hours prior to a FDG PET/CT scan, as exercise can cause increased FDG uptake in the groups of muscles involved.

- Recognition of false-positive results on FDGPET/CT is necessary and clinicians need to be mindful of activity which is strenuous and may be overlooked by patients as not considered 'exercise', such as the use of crutches.

unnecessary tests/imaging for the patient. Therefore, knowledge and understanding of benign causes of FDG uptake is essential.

Glucose metabolism is increased in skeletal muscles during exercise. FDG is a widely used tracer and an excellent and sensitive marker for changes in glucose metabolism. Guidelines suggest patients should avoid strenuous exercise for at least 6 hours before the FDG PET/CT, and preferably for 24 hours. ${ }^{3}$ We illustrate an unusual case of avid FDG uptake in skeletal muscles in a patient who had been using crutches prior to his scan. As the use of crutches does not fall within the category of strenuous exercise, it can be overlooked as a cause of increased glucose metabolism in skeletal muscle. Clinicians therefore need to be mindful of ordering PET/CT scans following surgery that necessitates crutches use to avoid the risk of misdiagnosis and incorrect patient management. The false-positive finding caused by crutches use was initially of great concern as melanoma metastases are notorious for intense FDG activity similar to that observed here.

Contributors LP and RM gathered the information for this case report, prepared the manuscript and had final approval of the manuscript.

Funding The authors have not declared a specific grant for this research from any funding agency in the public, commercial or not-for-profit sectors.

Competing interests None declared.

Patient consent Obtained.

Provenance and peer review Not commissioned; externally peer reviewed.

\section{REFERENCES}

1 Akcali C, Zincirkeser S, Erbagcý Z, et al. Detection of metastases in patients with cutaneous melanoma using FDG-PET/CT.J Int Med Res 2007:35:547-53. 
2 Vensby PH, Schmidt G, Kjær A, et al. The value of FDG PET/CT for follow-up of patients with melanoma: a retrospective analysis. Am J Nucl Med Mol Imaging 2017;7:255-62.
3 Boellaard R, Delgado-Bolton R, Oyen WJ, et al. FDG PET/CT: EANM procedure guidelines for tumour imaging: version 2.0. Eur J Nucl Med Mol Imaging 2015:42:328-54.

Copyright 2018 BMJ Publishing Group. All rights reserved. For permission to reuse any of this content visit http://group.bmj.com/group/rights-licensing/permissions.

BMJ Case Report Fellows may re-use this article for personal use and teaching without any further permission.

Become a Fellow of BMJ Case Reports today and you can:

- Submit as many cases as you like

- Enjoy fast sympathetic peer review and rapid publication of accepted articles

- Access all the published articles

- Re-use any of the published material for personal use and teaching without further permission

For information on Institutional Fellowships contact consortiasales@bmjgroup.com

Visit casereports.bmj.com for more articles like this and to become a Fellow 